\title{
FINANCIAL SERVICE PROVIDERS: DOES IT MATTER IF BANKS DON'T BEHAVE ETHICALLY?
}

\section{Running Head: Ethical banking and consumer behaviour}

\author{
Zoe Patterson $^{\mathrm{a}}$ and Dr Morven G. McEachern ${ }^{\mathrm{b} *}$
}

aAlliance Manchester Business School, University of Manchester, Manchester, England, UK.

${ }^{b}$ Huddersfield Business School, University of Huddersfield, Huddersfield, HD1 3HE, UK, E-mail: m.mceachern@hud.ac.uk *Corresponding author 


\title{
Financial Service Providers: Does It Matter If Banks Don't Behave Ethically?
}

\begin{abstract}
The ethical consumer literature predominantly concentrates on fast moving consuming goods and thus, neglects insights to consumer behavior within ethical services. As the financial services sector continues to grow in the UK, this paper addresses this anomaly by providing further insight into consumers and their ethical banking practices. More specifically, it examines their motivations as well as the trade-offs and barriers which prevent greater uptake. Using a combination of in-depth interviews and projective techniques, the research draws on Freestone and McGoldrick's (2008) model to reveal a lack of awareness towards ethical financial service providers and sheds light on various perceptions regarding what constitutes an ethical financial service. Additionally, numerous underlying personal benefits of ethical financial services became apparent alongside consumer expectations of customer care. In conclusion, our findings help to create a revised model which identifies more precisely the stages of ethical awareness, motivation and behaviour of ethical consumers both in the context of ethical financial services but also ethical consumption practices in general.
\end{abstract}

Keywords: Financial services, ethical consumer behaviour, ethical motivation, consumer awareness and behaviour; phenomenological interviews. 


\section{Introduction}

Western Europe and the UK are seen as the "epicentre" of the ethical consumption market (Carrington et al., 2014; Oh \& Yoon, 2014, p. 278). From a UK perspective, this is evident from an ethical consumer market valued at $£ 81.3$ billion in 2017 - marking the fourteenth year of consecutive growth for this sector (Ethical Consumer Report, 2017). This indicates a growing commitment from consumers to make informed purchases and engage with responsible consumption when shopping (see Carrigan \& Bosangit, 2016) especially purchases which revolve around issues such as social justice, human rights, animal welfare and environmental concerns (Schröder \& McEachern, 2004; Harrison et al., 2005; Cho \& Krasser, 2011; Sudbury-Riley et al., 2012). Similarly, the ethical financial services sector witnessed a $7.1 \%$ growth rate throughout $2011-2014$ and is currently valued at $£ 22.12$ billion and constitutes a fifth of the banking sector (Keynote, 2015, p.128). This growth is partly due to mainstream banks receiving significant, negative media attention during the financial crisis focusing on financial investment in harmful activities such as fossil fuels and on branch closures and are therefore, seen to be putting profits first and customers second (Move Your Money, 2016). Consequently, experts have recently speculated that all banks need to encompass social purpose into the core of their strategies to avoid long-term decline (Klooster \& Meyer, 2015). Despite this observation, there continues to be an over-emphasis on ethical fast-moving consumer goods by consumer behaviour researchers and less focus on ethical services, such as the financial services sector. While there are limited investigations into the investment banking sector (see Lewis, 2001; Buttle, 2007), the prominent role of everyday banking in the retail marketplace, as well as the fact that ethical consumer behaviour is highly contextualised (Carrigan, 2017), indicates that greater understanding is needed regarding consumer awareness, motivation and behaviour towards their use of ethical banking services.

A variety of banking services are accessible to consumers in the UK, ranging from commercial banks, building societies, co-operative banks and credit unions, each of which can potentially be categorised as an ethical bank (Buddyloans, 2017) ${ }^{1}$. Following Mitchell et al.'s (1992) categorisation of ethical banking behaviour, Move Your Money (2014) concludes that a bank is deemed ethical if it is able to satisfy a combination of four main aspects; honesty, customer service, culture and the real economy. For example, honesty is present when a financial institution pays its taxes and obeys the law (Move Your Money, 2014). In

\footnotetext{
${ }^{1}$ A description of each of the banking service types can be found at www.buddyloans.com.
} 
addition, a bank may be considered ethical if it is found to deliver high levels of customer services which encompass minimal complaints and a high level of customer satisfaction (Move Your Money, 2014). While this also seems like a rather basic premise to be expected with all banks; it does constitute a logical ethical pillar in reality considering the UK financial services sector's tendencies to mislead its customers such as in the case of payment protection insurance (PPI) (see Straus, 2015 for more details on PPI). A bank's culture can also enhance or hinder its ethical stance and here in the UK, unethical banking cultures remain under close scrutiny by the media, for example, the Royal Bank of Scotland handed out bonuses despite an eighth consecutive year of losses (Treanor and Rushe, 2012).

The Move Your Money (2014) scoring system determines how ethical each banking institution is by their allocated switch score (see Table 1). Thus, the higher the switch score the more ethical the bank. No financial service provider obtains a full score of 20, which indicates that there is still room for much ethical improvement. This Ethical Scorecard is currently observed as the most accurate way to gain an overarching understanding of the ethical banking landscape (Keynote, 2015). From the barometers measured by Move Your Money, it is evident that banks are subject to lower ethical thresholds compared to other sectors as a food manufacturer would not be labelled ethical if they were simply found to be honest and offer high levels of customer service, it would just simply be seen as good business. As a banking institution can claim an ethical position by altering relatively little in the way of banking practices, it is timely to identify whether this is sufficient for consumers and observe the ethical criteria (if any) that consumers use to evaluate and select banking services.

\section{Insert Table 1 near here}

Furthermore, research which provides an understanding into consumer awareness, motives and action becomes a priority in any ethical sector if its consumption rate aims to increase (Szmigin et al., 2009; Jägel et al., 2012; McEachern, 2015). Therefore, to help gain an overarching understanding of consumers and the ethical banking landscape, the objectives of the study are threefold. Firstly, using Table 1 as a benchmark, current trends in the 
usage/non-usage of the ethical banking sector are identified. This will help to satisfy the research questions - which ethical banks are consumers aware of and do they use them? Secondly, we explore the underpinning motivations of consumers who bank ethically. Thus, answering the research question - why do consumers bank/not bank ethically? Thirdly, we examine the behavioural trade-offs and barriers which impede the greater uptake of ethical banking services. This will help to satisfy the research question - why is the ethical banking sector not growing as much as other ethical product sectors? This research is important from both a theoretical and practical perspective. On a theoretical level, the study draws on motivation theory and Freestone and McGoldrick's (2008) model to help improve our understanding of consumer awareness of ethical banking activities as well as advance our knowledge of the underpinning motives for banking ethically and their subsequent banking choices. From a practical perspective, the results will help facilitate the composition of ethical financial service strategies that can engage consumers and gain their trust.

The paper proceeds by presenting an overview of the literature surrounding the role of consumer awareness as a precursor to ethical consumption, and motivation for engaging with ethical consumption behaviours. Following details of the adopted methodology, the findings and discussion of the research are then presented. Finally, the paper closes with emerging conclusions along with our proposed revised model, recommendations, limitations and avenues for future research.

\section{The Ethical Consumer: Awareness, Motivation \& Action}

Ethical consumption is defined as "an ethical/moral dimension, where the hedonic function and/ or product utility are, to some extent, subordinated by concerns about right and wrong and consequences of consumption acts" (Gregory-Smith et al., 2013, p.1204; Oh \& Yoon, 2014). Ethical consumers not only support ethical brands by making positive purchases, but also use their purchase power as a weapon and avoid or boycott ${ }^{2}$ companies or goods they do not perceive to be ethical (Szmigin et al., 2009), An important influence upon whether to engage or not engage with ethical consumption often depends upon ethical awareness (Berry $\&$ McEachern, 2005). Although sources of information available to ethical consumers are numerous, ranging from personal to non-personal sources, and those categorised as marketer

\footnotetext{
${ }^{2}$ A boycott is "a typical action through which consumers deliberatively avoid purchasing products offered by firms which violate shared ethical principles” (Gianluigi, 2009, p.2).
} 
controlled or non-marketer controlled sources (Assael, 2004; Uusitalo \& Oksanen, 2004), other determinants that can influence the extent of information search include the consumer's level of involvement, perceived risk or uncertainty (Moorthy et al., 1997; McEachern \& Warnaby, 2008). In the context of financial information provision, access to financial information helps to improve literacy, make better financial decisions and encourage more desirable financial behaviour (Xiao \& O’Neill, 2016). Here, publications such as 'Which' and 'Ethical Consumer' and consumer advocate websites (e.g. see Paul Lewis Money Matters website) play a crucial role in enabling consumers to identify ethical products more effectively and thereby influence ethical motivations (Berry \& McEachern, 2005; Chatzidakis \& Mitussis, 2007; Young et al., 2010).

Motivation has been generally understood as a reason for behaviour and may be overt or hidden (Moisander, 2007). Moreover, motivation is a key aspect in determining why consumers purchase ethical products/services and is frequently defined as a consequence of the adoption of ethical theories, mainly virtue ethics, deontological ethics and utilitarianism (de Colle and Werhane, 2008). However, such theories may be insufficient to determine ethical motivation as they often fail to represent the multitude of ethical stances present in reality (Cherrier, 2007), resulting in a lack of foundational theory, truth or all-encompassing narrative which is applicable to all consumers (Barnett et al., 2017). Furthermore, this diversification of society creates a variety of ethical foundations to drive consumer ethical motivations which consequently creates an "inability to know" what should be considered ethical (Beck, 1999, p.131). According to this speculation, a multitude of consumer motivations to engage with ethical financial service providers should be present. Thus, emphasising the need for relevant motivation theories to understand consumer behavioural responses to ethical banking services.

A key motivational theory is Maslow's (1943) hierarchy of needs which proposes that individuals are motivated to satisfy their basic physiological needs and then subsequently fulfil their safety needs, love needs, ego-centric needs and finally become motivated to achieve self-actualisation. This theory was later revised to include cognitive needs, aesthetics (Maslow, 1970a) and the final stage of transcendence needs (Maslow, 1970b). Thus, concluding that consumer behaviour may be motivated by differing needs depending on the individual. Due to a shift in consumer values, it is argued that ethical purchasing is used as a means to self-actualisation and self-fulfilment (Solomon et al., 2016). Consequently, similar to other classical theories of motivation (e.g. Hertzberg's two-factor theory - see House and 
Wigdor, 1967; Vroom's expectancy model - see Eerde and Thierry, 1996), Maslow's hierarchy of needs is widely criticised and seen as being of declining importance (Daniels, 1982; Wicker et al., 1993) and thus, unable to provide a realistic and comprehensive stance to assess the motives behind consumers and their selection of ethical financial service providers.

In contrast, Freestone and McGoldrick (2008) recommend using the Decisional Balance Scale within the context of the ethical decision making process. They argue that this not only assesses the motivation (i.e. concern) behind the decision making process but also highlights the trade-offs with a particular action (Janis \& Mann, 1977; Velicer et al., 1985). In addition, Freestone and McGoldrick's model (2008) incorporates the Stages of Change Model (see Prochaska et al., 1992 for a review of this model) which depicts stages of behavioral change within an ethical decision making context (see Figure 1). Together, both components provide a basis for determining a particular level of motivation experienced by the consumer as well as help to identify further opportunities to progress by intervening and targeting motivations attached to later stages.

\section{Insert Figure 1 near here}

For example, an individual who falls into Stage 1 - the 'not noticed this issue' category has no awareness and thus, no concern for the ethical issue at hand. In the context of banking, people who fall into this category could be oblivious to negative press regarding some unethical banking practices. As the remaining five stages encompass a sense of awareness, Stage 2 categorises consumers who are aware yet are not very concerned and are thus, unlikely to adapt their purchase behaviour. It is possible this category could include those with conflicting values to bank ethically which have been prioritised. Stage 3 acknowledges a presence of concern amongst individuals and categorises consumers who have decided not to take action, perhaps due to the elements of hassle and inconvenience of switching to an ethical banking alternative. Stage four deals with individuals who intend to take action, yet no action has occurred and in reality consumers may decide not to enact such intention. In contrast, Stages five and six refers to consumers who have taken action which has been further distinguished into minor and major action. In the context of banking, having an account with an ethical financial service provider but simultaneously using other 
mainstream provider accounts could constitute minor action whereas major action is more likely to encompass an individual's complete financial services being provided by a reputable, ethical institution.

Freestone and McGoldrick (2008) provide strong empirical evidence that as an individual moves through awareness, concern (i.e. motivation) and action, a shift simultaneously occurs among the Decisional Balance Scale. Henceforth, an individual in the early stages of awareness is unlikely to hold the view that ethical actions have social and personal benefits and the negative aspects of behavioural change will subsequently outweigh the positives. Although, Bucic et al. (2012) argue that greater awareness does not necessarily transpire into purchase behaviour which further compliments previous research that educated consumers who have awareness of ethical issues may not adopt such knowledge into their consumption (see for example Caminiti, 1992), Freestone and McGoldrick (2008) note that subjectivity and situational influence can determine the path of consumption in reality. In the absence of previous research into consumer behaviour and ethical banking, conflicting findings have also filtered into other sectors such as the Fairtrade food sector. Here, some authors regard every purchaser's motivation as ethical (e.g. Carrington et al., 2010), while others' empirically disregard such findings and prove that self-interest values are a major contributor in exercising such behaviour (e.g. Ozcaglar-Toulouse et al., 2006; Yamaoh et al., 2014). Similarly, in the eco-clothing sector, altruistic motivators such as environmentalism is present yet, other factors such as value for money, image and well-being have also emerged as a major influence (Jägel et al., 2012). Thus, ethical concerns are not always the primary motivators of consumption as egoistic and self-serving factors can also influence intent and behaviour which is likely to be mirrored in terms of ethical banking behaviours. As a result of such conflicting interpretations of the rational consumer, (see also critiques of Maslow's hierarchy of needs), this may render the incremental, progression-type structure of Freestone and McGoldrick's (2008) model inadequate to capture the multiplicity of ethical positions regarding the uptake of ethical financial services. Nevertheless, while the primary motivator behind ethical consumption remains ambiguous (Yamaoh et al., 2014); there is overwhelming evidence that motivation is a pre-requisite and a strong link to exercising ethical consumption (Lewis, 2001; Buttle, 2007; Freestone \& McGoldrick, 2008).

Many studies in the ethical field have focused on motivation through examining attitudes and intentions towards ethical consumption rather than actual purchasing behaviour (for a review of this issue, see McEachern \& Carrigan, 2012). However, this has often led to 
an attitude-behaviour gap (Harrison et al., 2005; Carrington et al., 2010; Hassan et al., 2014) which arises as a result of two scenarios. Firstly, some authors argue that its presence is a consequence of self-reported methodological methods used by researchers' which are prone to social desirability bias as they concentrate on intentions and possible future behaviours which may not represent reality (Carrigan \& Attalla, 2001; Auger \& Devinney, 2007). This creates a gap as it grants participants the freedom to hide their true values in exchange for giving researchers the perceived "right" answer (Clavin \& Lewis, 2005). Secondly, others outline that the attitude-behaviour gap is widened due to the sway of direct and indirect decisional factors (de Pelsmacker \& Janssens, 2007; Vermeir \& Verbeke, 2008). Carrington et al., (2010) argues however, that it is probably a blend of these two speculations as intention does not always amount into behaviour because ethical concerns are subject to the process of prioritization in reality. That is to say, when the secondary prioritization of core values fail to integrate ethical consumption into consumer lifestyles, such individuals are unlikely to consume ethical products/services consistently and henceforth create a misalignment of behaviour (Carrington et al., 2014).

Due to the limited academic focus on consumers and the ethical banking sector, existing research from other ethical sectors illustrates that the most common trade-offs to the uptake of ethical products are convenience (Memery et al., 2005) and price (Auger et al., 2003). In addition, value trade-offs are apparent when the end states of consuming ethically conflict (Schroder \& McEachern, 2004; Jägel et al., 2012). Equally, Shaw and Clarke (1999) propose that choice, availability and information can constitute a barrier to ethical consumption. Belk et al., (2005) add that ethical barriers to the ethical uptake of products/services can arise internally as they usually encompass a lack of concern due to a lack of attachment, a stance that views unethical activity as the norm of society and/or that the outcomes of unethical behaviours are not experienced by the individual. Similarly in the context of financial service providers, Colgate and Lang (2001) conclude that customers will be less likely to switch financial service provider due to apathy factors encompassing the view that "all banks are the same" and that switching entails "too much bother". An additional motivating factor often raised in the context of banking preferences is the subject of risk. Here, the commonly held perception is that ethical account holders have another account elsewhere with a mainstream bank as it is viewed as "imprudent" to place all their eggs in one ethical basket (Lewis \& Mackenzie, 2000; Lewis, 2001). Therefore, further investigation concerning consumer insight into consumer awareness of the ethical banking 
sector; motivations for banking/not banking ethically; and the barriers/trade-off behaviours which prevent further engagement with the ethical financial services sector is warranted.

\section{Adopted Methodology}

This research takes an interpretivist approach as it possesses the ability to offer a flexible means to generate a greater understanding of perspectives and adds contextual, in-depth assessments of the topic (Myers, 1997; Ritchie \& Lewis, 2003). Consequently, qualitative research in the form of in-depth interviews are adopted as they provide a useful method of uncovering underlying motivations, attitudes and beliefs (Supphellen, 2000). Whilst focus groups have previously been deemed a desirable form of data collection in an ethical context (e.g. see Lewis, 2001), in-depth interviews provide a private and less structured means of data collection which helps limit the presence of social desirability bias (Belk et al., 2005; Auger \& Devinney, 2007). The in-depth interviews took place with British consumers over the summer months of 2016 and typically lasted around 60 minutes. Pseudonyms were used to conceal the identities of each respondent and assure anonymity. The interview guide was designed to gain insight into consumer awareness of the financial services sector; their banking activities (i.e. relationships with their bank, the type of accounts they had) as well as the emphasis they placed on ethical values being adopted by the financial services sector.

To maximize the information obtained from participants, projective techniques are adopted to help overcome potential communication barriers (Steinman, 2009) and again limit the presence of social desirability bias amongst participants (Donoghue, 2000; McEachern, 2015). Therefore, scenario building exercises, photo elicitation and choice ordering are employed to enhance interpretative accuracy (Donoghue, 2000). Here, scenario building helped to shed light on participants' perceptions and associations of banks and therefore offer a popular means of determining brand personality attributes with well-known comparisons such as cars and animals (Oswick \& Montgomery, 1999; The Financial Brand, 2010). Photo elicitation is also used to help engage the participant for longer (Collier, 1987), lessen the awkwardness of the interview scenario (Clark- Ibáñez, 2004), potentially sharpen memories of particular feelings or events (Collier, 1987; Clark- Ibáñez, 2004) and finally, generate an opportunity to probe into underlying perceptions and values (Epstein et al., 2006). Although time consuming in terms of preparation and interpretation of responses (Meo, 2010), ample time has been prescribed to preparing and interpreting the interview process. Overall, the use 
of multiple projective techniques alongside standard questioning helps enhance the overall trustworthiness of the data collection process through triangulation (Patton, 2002).

Convenience sampling attaches much criticism in qualitative research as it is deemed to produce an element of bias and unknown incompleteness as individuals that are readily available are unlikely to be the most adequate and informative sources (Farrokhi \& Mahmoudi-Hamidabad, 2012). Due to the sensitive nature of banking, perhaps due to issues around security, convenience sampling of adult British nationals was a necessary mode of recruitment in this instance. The sample consisted of seven individuals and recruitment stopped after saturation occurred whereby new data failed to provide additional insight (Mason, 2010). After the sixth interview no new themes and codes emerged which supports guidelines that saturation can occur in as little as six interviews (Guest et al., 2006). All seven interviews took place in a familiar and public environment to promote a feeling of equality and relaxation amongst participants.

Due to a lack of previous literature about consumers and the ethical financial services sector, thematic analysis was selected to derivate key information from the data set (AttrideStirling, 2001). In an attempt to dissolve the thematic disadvantage of researcher reliability, inter-coder reliability was used with three interview transcripts which subsequently enhanced trustworthiness (Miles \& Huberman, 1994). Using Thomas's (2006) process of inductive coding as a general guide, the transcripts were compiled on $\mathrm{NVivo}^{3}$ in an attempt to instil accuracy and efficiency amongst multiple sources of unstructured data (Welsh, 2002). From the interview transcripts, code overlap and redundancy amongst the categories was reduced to reveal five key themes: banking and privacy; levels of awareness and perceptions of ethical banking; ethical motivation, skepticism of banking practices; and trade-offs/barriers to the uptake of ethical financial services.

\section{Findings \& Discussion}

Table 2 provides an overview of the sample characteristics. A wide age range of consumers were obtained, ranging from 23 to 83 years old, enabling this study to provide greater insight into the largely neglected perceptions and behaviours of the younger generation which is essential given that the younger population is more susceptible to the pull of ethical banking

\footnotetext{
${ }^{3} \mathrm{NVivo}$ is a software programme that supports qualitative research. It's designed to help you organize, analyze and find insights in unstructured, or qualitative data.
} 
(Keynote, 2015). Echoing the findings of Lewis (2001), more ethical banking customers appeared to originate from those participants who worked in a caring profession. However, no individual appeared to rely solely on an ethical bank or ethical banking services and instead were found to have multiple accounts in a mixture of ethical and mainstream domains.

Insert Table 2 near here

\section{Banking: A Private versus Public Activity}

Unlike many other consumption behaviours, it was apparent that choices of financial service providers were not a common topic of conversation outside of the confines of participants' homes. On inquiring about the influence of others upon an individual's ethical banking uptake, Belle (55, Dentist) stated that "people don't really talk about who they bank with. I don't have a clue who anyone banks with. It is funny because we talk about money all the time". Rebecca (83, retired) suggested that this lack of openness was common as "banking is seen as a private activity". This compliments previous speculation concerning the sensitivity of consumer banking and provides further justification for convenience sampling. Interestingly, although similar views around conversations on everyday banking activities were shared by younger participants, they acknowledged a greater willingness to divulge banking information about who they bank with but only if "they were having issues or something" (Alexander, 23, student) or when friends or family seek recommendations. Such observations around privacy concerning consumption behaviours of financial services could have significant implications for consumer awareness of ethical financial service providers.

\section{Ethical Awareness \& Perceptions of Financial Service Providers}

Aside from customers of the Co-operative Bank who are predominately marketed on their ethical appeal, many of those who banked with a building society did not discuss any ethical association. However, Matthew (55, retired) perhaps as a result of his previous occupation as a bank official, noted that Nationwide and other building societies may be ethical because "nobody owns them" and questioned the ethical democratic benefits by claiming that Nationwide in particular "is no more democratic than a board...It is not that they are 
unethical but just not more than a bank". Interestingly, some participants did not question the ethical status once they were made aware of their respective bank's ethical score (see Table 1). For instance, Sarah (23, Housing Officer) stated "I didn't know it but I am not surprised" when discussing Nationwide's ethical score. This challenges the presumption that individuals need to be aware and motivated to bank ethically. In some cases, there is comfort in the lack of awareness of unethical banking practices. For example, the following quote reveals that some individuals also choose to turn a blind eye to unethical practices as other attributes such as rates, repayment period etc. were seen as being more important. Consequently, this finding strengthens Shaw and Clarke's (1999) proposition that some attempts to enhance awareness of an ethical product/service can be unwelcomed:

"They say ignorance is bliss. What you don't know you don't worry about. If you are aware then it does make you think more about it. But from my own perspective it has all been about borrowing money and getting the best rate because you got your own worries so you don't really consider things that don't really affect you...In an ideal world where people look out for each other we should think of others, but in banking I don't think this is really present" (Belle, 55, Dentist).

In contrast, some participants were aware, concerned and had taken minor action as they both had an ethical and mainstream account. Here, differences were acknowledged between types of financial institutions as building societies offered the most competitive rates on savings accounts and mainstream banks were viewed more favourably in relation to the return offered from current accounts as well as offer current and up-to-date products and services. Thus, echoing Cherrier's (2007) observation of a fragmented ethical landscape.

The transferability of Buttle's (2007) investment banking typologies are also heavily questioned in the context of everyday ethical consumer banking. Here, Richard (23, Production analyst) highlighted that "the term ethical banking can be quite subjective". This is reinforced by Matthew (55, retired) who states that "the definition of ethical keeps changing and evolving. But more importantly, it depends on who you talk to... Ethics is to a degree in the eye of the beholder". Other participants emphasised their understanding of ethical banking as being "about going the extra mile to please its customers" (Rebecca, 83 retired). Kate (54, monographer) also talked at length about what is perceived as ethical and its links to good customer service; "Banking is like a relationship. Even a marriage. And if you have a bad partnership and you don't have good communication then it is never going to work". 
In relation to whether ethical banking helps improve social justice and wealth distribution, a bank's role in such activity was questioned by some. For example, Rebecca (83, retired) stated that "I do think that some people need more help than others but I think it is wrong to invest in a bank which does this", and instead (as did Alexander, 23, student) felt it was a charities job to exercise this behaviour. Similarly, Matthew (55, retired) argued that "the tax system is about the only way to get wealth distribution going". Alternatively, many agreed that ethical banking improves environmental issues and sustainability and that ethical banking helps generate a small social return in addition to offering good rates:

"When I think of ethical banking I think of the effects on the wider population as well as investment. So ethical banking does not just extend to customers of the bank. It does affect everyone like protecting the environment" (Richard, 23, Production analyst).

Aside from the differing definitions of ethical banking, the projective techniques helped depict contrasting motivations and a variety of value systems amongst participants, revealing some participants who were uncomfortable exploiting others and those who were more focused on more direct personal benefits. For instance, Matthew (55, retired) felt that "there is nothing wrong with holding shares in oil companies for example, we need them. If they make money then great" whereas others felt the "need to look at the bigger picture and not just focus on ourselves" (Sarah, 23 Housing Officer).

\section{Ethical Motivation}

It is evident that ethical banking promoted many feelings of self-gratification amongst individuals which mirrors the general trend in the ethical literature that self-oriented motivations have the ability to influence the uptake of ethical products (Ozcaglar-Toulouse $e t$ al. 2006; Jägel et al. 2012; Yamaoh et al. 2014). This finding is valuable as the current study is able to evidence that personal benefits can amount to driving use in the ethical financial services domain. Furthermore, it subsequently disproves the perception that all motivations have to be ethical when consuming ethical products (e.g. see original claim of Carrington et al. 2010). For example, a common finding was that "Banking ethically is an easy way to feel good" (Sarah, 23, Housing Officer) as it makes individuals "feel like a better person...[and] does not require a lot of thought" (Richard, 23, Production analyst). It was also found that 
banking ethically helped elevate feelings of guilt and promoted a clearer conscience whether this was by ethical investments or charitable giving. As a result, ethical banking was able to offer associative benefits as it signified that consumers were against particular practices and therefore complimented other ethical behaviours and even their sense of identity. This directly compliments Langeland's (1998) findings that ethical consumption can be used as a tool in some instances to obtain a specific identity.

Banking with an ethical institution was motivating for some as it also complemented their sense of duty to be a good citizen. Here, Kate (54, Monographer) felt that ethics was regarded as "an unspoken moral code". Alexander (23, Student) who banked with the cooperative Bank, added that meeting these codes helped individuals "do [their] bit to make things a bit better" and subsequently help create a sense of belonging in a community. Additionally, Matthew (55, retired) felt that a sense of belonging was created in banking with a Credit Union also because "if you aren't paying your loan back you would be letting down your neighbours too." However, he further conveyed that this benefit is being diluted now as "people care less about the community than they once did. I think people are only really interested in their own lives and interests now" (Matthew).

While interviewees commonly identified ethical banking as a means of differentiation in the financial services sector, benefits such as loyalty, positive word of mouth and new customers were valued just as much. Here, Belle (55, Dentist) added that "if you could get the best of both worlds like good interest rates, friendly bank manager and good banking habits then why wouldn't you change". Moreover, an ethical stance can only be stretched to a certain degree before customers will begin to feel less of a priority and thus upset the balance. For example, Rebecca (83, retired) felt that she could "see the benefits and rationale for using ethical banking for helping the environment as it affects us all but I don't see how [addressing poverty, human rights etc.] could benefit people directly" which implies that a bank need only be ethical to the extent to which it benefits the customer.

\section{Skepticism of Retail Banking Practices}

There was a sense that "building societies are the lesser of the evils in banking" (Rebecca, 83, Retired) due to them being more customer orientated and democratic. While some participants failed to exercise their right to vote on certain policies, it was noted sceptically that "giving the customer more of a say is clever, it makes them feel valued and that these 
banks seem to care about their interests overall really” (Belle, 55, Dentist). In addition, these activities were seen to make such institutions "stand out from other self-serving, negative banks" (Kate, 54, Monographer). Consequently, there was a desire for all banks to display more caring and responsible qualities:

"Knowing that Nationwide is not going to invest in harmful practices makes it seem like a good citizen in a way, more human and understanding of the community" (Rebecca, 83, Retired);

"[The Co-operative Bank] don't punish customers for small mistakes like going over their overdraft...[it] sets them apart from other banks as they would jump at the chance to earn more money off their customers. It is almost like they are waiting for them to make a mistake" (Richard, 23, Production Analyst).

Skepticism towards banks featured strongly amongst participants which is not that surprising given the UK financial sector's recent scandals (e.g. PPI - see Straus, 2015; CEO salaries and bonuses - see Treanor \& Rushe, 2012) and Government bailouts witnessed over the last decade (e.g. Royal Bank of Scotland, Northern Rock). For example:

"Unfortunately, banks have a tendency to take advantage of their customers, take the whole PPI scandal for instance" (Belle, 53, Dentist);

"With the recent banking crisis it seems that it is normal for one to expect some form of disappointment from their bank" (Rebecca, 83, Retired);

"There is such a little difference [in rates] in reality I think, so it is more important to bank with someone who treats you well and that you can trust" (Sarah, 23, Housing Officer).

Complimenting Klooster and Meyer's (2014) recommendations that honesty needs to be enacted into any bank to ensure trust and survival, the scenario building exercises raised many questions from the participants around honesty - "certainly if you haven't got honesty then you haven 't got anything" (Matthew, 55, Retired). Therefore, to help spread any potential risk, all participants had multiple accounts combining a mixture of ethical and mainstream banking institutions as they adopted the philosophy of "never put all your eggs into one basket" (Belle, 55, Dentist). This is seen as 'normal' practice (see Lewis 2001; Lewis \& Mackenzie 2000), yet, the current study suggests that this practice was motivated by fears around losing money rather than a wish to offset unethical banking practices. Here, 
Alexander (23, student) perceived an "element of risk attached to the Co-operative Bank at the moment" and thus felt more secure in investing his savings with another bank, pointing to many trade-offs and barriers attached to ethical banking.

\section{Trade-off/Barriers to Ethical Banking Services}

Despite their ethical foundations, a common reservation held amongst participants was the Co-operative Bank's lack of profitability in recent years. Here, Rebecca (83, Retired) states "the Co-operative Bank are the most popular ethical bank and I suppose if they were backlogged with debt by banking responsibly then it says that it is difficult to ensure stability and do good simultaneously." In addition, awareness of contradictory behaviours demonstrated by the lower-scoring banks (see Table 1) such as mis-selling of PPI, disproportionate banker's bonuses and customer service issues made many doubt the strength of an ethical banking label (see Treanor \& Rushe, 2012; Straus, 2015). One extreme view held towards such contradictory behaviour was that these activities have the ability to make consumers "just lose faith in it all" (Alexander, 23, Student). Sarah also commented on the value of having a few ethical banks amongst others who were not as ethical saying that "a bank by itself isn't going to make the difference. But if all the banks and all of the people are doing it then a difference would be made."

Other trade-offs relating to the service offered by ethical institutions were apparent. For example, Rebecca (83, Retired) was unable to get a mortgage with Nationwide and had to settle with a mainstream bank, "I needed a mortgage so beggars can't really be choosers". This also draws attention to the irresponsible lending practices of the lower-scoring banks, a criterion which does not appear on the Ethical Scorecard (see Table 1). Convenience was also a major influence amongst most participants' banking practices which compliments Memery et al.'s (2005) finding in the general ethical literature. Overall, many participants were reluctant to switch banks and tended only to do so if they were "chasing the rate" (Matthew, 55, Retired) or had experienced extreme disappointment with their previous banks.

\section{Conclusions, Recommendations \& Proposed Avenues of Future Research}

Due to the empirical gap surrounding consumers and their ethical banking behaviours, this study has facilitated a greater insight into consumer awareness, motivations and behavioural 
actions towards ethical banking services. Surprisingly, despite holding bank accounts with high-scoring ethical banks, consumers' awareness of ethical banking practices was limited, with no-one mentioning the various publications and/or websites that are available to learn/gain financial information from. Additionally, while consumers are happy to discuss and compare other everyday aspects of consumption, the lack of openness and public discussion around the consumption of banking services clearly impacts on the selection of ethical financial service provider. As the power of normative influences is heightened in the event of consuming a product/service in public (see Shaw \& Clarke, 1999; Belk et al., 2005), there is scope for ethical banks to create more cognitive dissonance around competitor brands in their advertising and promotion of their financial services.

Despite the destructive impact of the banking crisis and the tremors of unethical activity being referenced to by all participants, it is evident that motivations to bank ethically have the ability to counterbalance trade-offs to a certain extent. In contrast to much ethical consumer literature (see for example Harrison et al., 2005; Carrington et al., 2010, 2014; Hassan et al., 2014), these findings are limited regarding the presence of attitude-behaviour gaps. This is sometimes due to an unwillingness to sacrifice personal benefits and/or a lack of prioritisation of ethical concerns. Although some consumers documented the importance of the environment and others emphasised the importance of the social, it would be helpful for future research to examine why such criteria are preferred as secondary or tertiary influences and in what contexts are they more prominent. While there was much debate about what 'ethical banking' looked like, many consumers spoke of how banking with an ethical service provider removed personal feelings of guilt around harmful banking practices (e.g. unethical investments in fossil fuels) and helped promote an ethical identity (see also Langeland, 1998) albeit a fragmented one (Cherrier, 2007; Barnett et al., 2017). However, the prominence of satisfying personal benefits is key amongst the sample and thus, it is argued that consumers demonstrate a strong preference for banks that put the customer first in the majority of situations. Finally, despite some skepticism, UK consumers are willing to demonstrate an element of trust when a bank displays more caring and responsible qualities. However, it is clear that customer care should not be compromised in a financial service providers' effort to serve the wider interests of society.

Theoretically, there is an element of transferability from the literature surrounding fast moving consumer goods to the ethical services domain but the applicability of previous financial services literature regarding ethical investor motivations has limited transferability. 
As consumers are largely unaware of the ethical status of their banking institution (especially those who bank with building societies) and thus, do not proactively chose or are motivated to bank with that institution for that reason, the applicability of Freestone and McGoldrick's (2008) stages of change model in the context of consumer ethical banking may be questioned. In other words, an ethical action was taken by some consumers but the stages of awareness and concern were not surpassed. Perhaps this finding links to the ambiguous categorisation of "what is ethical?' when referring to the banking sphere? As a result, we build on Freestone and McGoldrick's (2008) stages and propose an adapted model (see Figure 2) which incorporates an additional stage of ethical unawareness, motivation and action whereby the ethical action takes place accidentally, either through convenience or priority of other personal characteristics (e.g. the bank is closer to where I live). Our adaptation offers a contrasting Stage 2, for consumers who are unaware and/or unconcerned about ethical issues but still due to other selfserving values (see Ozcaglar-Toulouse et al., 2006; Yamaoh et al., 2014), accidentally progress to Stages 5/6 (minor/major action). This revised model identifies more precisely the stages of ethical awareness, motivation and behaviour of ethical consumers both in the context of ethical banking but also ethical consumption practices in general.

\section{Insert Figure 2 near here}

Nevertheless, the current study is subject to various limitations. Firstly, it could be argued that the sample does not wholly represent the wider population as a limited sample size and age clusters are present. Secondly, the sample predominately focuses on customers of building societies rather than leading ethical banks (see Table 1) which may have overshadowed other motivations, trade-offs and barriers to bank ethically. Therefore, future research may wish to include a more balanced number of participants from banks and building societies as well as collect similar data on a larger, quantitative scale. Nevertheless, it could be argued that a study which focuses primarily on building societies is more representative of the current ethical banking landscape. Whilst it is acknowledged that every study has its limitations, the overall trustworthiness of the research gives it value. The quality and persuasiveness of the study was assessed using Lincoln and Guba's (1985) trustworthiness criteria of credibility, transferability, confirmability and dependability, which constitutes the generally accepted format of evaluation (Shenton, 2004). To ensure 
confirmability, a detailed portrayal of methods and examples of data analysis were included. In addition, direct quotations were used from the interviews to evidence findings and also rival conclusions were assessed throughout. In terms of dependability, three transcripts were independently checked to examine the researchers coding and no new themes emerged from this analysis. Details of participant demographics were included in the sample description in an attempt to make the study transferable. Finally, credibility of the research was mainly achieved by utilising a triangulation of methods (discussion questions, projective techniques and ranking exercises) to create a consistent insight into consumers and their awareness, motivation and behaviours regarding the context of ethical financial service providers.

Whilst this study was useful in identifying potential trade-offs/barriers towards ethical banking, data was collected from participants who banked ethically in practice. Henceforth, it may be useful to compare perceptions of ethical banking from customers of mainstream financial providers as it would enable the retail banking sector to gain relevant information to centre customer acquisition campaigns on. 


\section{References}

Assael, H. (2004). Consumer Behaviour: A Strategic Approach. Houghton Mifflin Company. Boston. MA.

Attride-Stirling, J. (2001). Thematic networks: An analytic tool for qualitative research. Qualitative Research, 1(3), 385-405.

Auger, P., Burke, P., Devinney, T.M. \& Louviere, J.J. (2003). What will consumers pay for social product features? Journal of Business Ethics, 42(3), 281-304.

Auger, P. \& Devinney, T.M. (2007). Do what consumers say matter? The misalignment of preferences with unconstrained ethical intentions, Journal of Business Ethics, 76(4), 361383.

Barnett, C., Clarke, N. \& Cloke, P. (2017). Whatever happened to ethical consumption? Reflecting on 'Consumer ethics: Articulating the subjects and spaces of ethical consumption', Journal of Consumer Ethics. 1(1), 11-21.

Beck, U. (1999). World Risk Society. Blackwell, London.

Belk, R.W., Devinney, T. \& Eckhardt, G. (2005). Consumer ethics across cultures. Consumption Markets \& Culture, 8(3), 275-289.

Berry, H., \& McEachern, M. (2005). Informing ethical consumers. In: The Ethical Consumer, (eds by Harrison, R., Newholm, T. and Shaw, D.). Sage Publications, London.

Bucic, T., Harris, J. \& Arli, D. (2012). Ethical consumers among the millennials: A crossnational study. Journal of Business Ethics, 110(1), 113-131.

Buddyloans (2017). Differences between banks, building societies and credit unions. [Online]. Available from https://www.buddyloans.com/blog/differences-between-banksbuilding-societies-and-credit-unions/ [Accessed 26 ${ }^{\text {th }}$ August, 2017].

Buttle, M. (2007). 'I'm not in it for the money': Constructing and mediating ethical reconnections in UK social banking. Geoforum, 38(6), 1076-1088.

Caminiti, S. (1992). The payoff from a good reputation, Fortune [online] Available from: http://archive.fortune.com/magazines/fortune/fortune_archive/1992/02/10/76053/index.htm [accessed 16 August, 2016].

Carrigan, M. (2017). Why are we still not ethical shoppers? Revisiting the myth of the ethical consumer - do ethics matter in purchase behaviour? Journal of Consumer Ethics. 1(1), 11-21.

Carrigan, M. \& Attalla, A. (2001). The myth of the ethical consumer - do ethics matter in purchase behaviour? Journal of Consumer Marketing, 18(7), 560-578. 
Carrigan, M. \& Bosangit, C. (2016). The challenges of responsible marketing and consumption. In: Ethics and Morality in Consumption: Interdisciplinary Perspectives Shaw, (ed. by D., Newholm, T., Chatzidakis, A. and Carrington, M.). pp. 75-96. Routledge, London.

Carrington, M., Neville, B. \& Whitwell, G. (2010). Why ethical consumers don't walk their talk: Towards a framework for understanding the gap between the ethical purchase intentions and actual buying behaviour of ethically minded consumers. Journal of Business Ethics, 97(1), 139-158.

Carrington, M.J., Neville, B.A. and Whitwell, G.J. (2014). Lost in translation: Exploring the ethical consumer intention-behavior gap. Journal of Business Research, 67(1), 2759-2767.

Chatzidakis, A. \& Mitussis, D. (2007). Computer ethics and consumer ethics: The impact of the internet on consumers' ethical decision-making process. Journal of Consumer Behaviour, 6(5), 305-320.

Cherrier, H. (2007). Ethical consumption practices: Co-production of self-expression and social recognition. Journal of Consumer Behaviour, 6(5), 321-335.

Cho, S. \& Krasser, A.H. (2011). What makes us care? The impact of cultural values, individual factors, and attention to media content on motivation for ethical consumerism. International Social Science Review, 86(1-2), 3-23.

Clark-Ibáñez, M. (2004). Framing the social world with photo-elicitation interviews. American Behavioral Scientist, 47(12), 1507-1527.

Clavin, B. \& Lewis, A. (2005). Focus groups on consumers' ethical beliefs. In: The Ethical Consumer. (Eds by Harrison, R., Newholm, T. and Shaw, D). 173-187. Sage Publishing, London.

Colgate, M. \& Lang, B. (2001). Switching barriers in consumer markets: An investigation of the financial services industry. Journal of Consumer Marketing, 18(4), 332-347.

Collier J. (1987). Visual anthropology's contribution to the field of anthropology. Visual Anthropology, 1(1), 37-46.

Daniels, M. (1982). The development of the concept of self-actualization in the writings of Abraham Maslow. Current Psychological Reviews, 2(1), 61-75.

de Colle, S. \& Werhane, P.H. (2008) Moral motivation across ethical theories: What can we learn for designing corporate ethics programs? Journal of Business Ethics 81(4), 751-764.

de Pelsmacker, P. \& Janssens, W. (2007). A model for fair trade buying behaviour: The role of perceived quantity and quality of information and of product-specific attitudes. Journal of Business Ethics, 75(4), 361-380. 
Donoghue, S. (2000). Projective techniques in consumer research. Journal of Family Ecology and Consumer Sciences /Tydskrif vir Gesinsekologie en Verbruikerswetenskappe, 28(1), 4753.

Eerde, W.V. \&Thierry, H. (1996). Vroom's expectancy models and work-related criteria: A meta-analysis. Journal of Applied Psychology, 81(5), 575-586.

Epstein, I., Stevens, B., McKeever, P. \& Baruchel, S. (2006). Photo elicitation interview (PEI): Using photos to elicit children's perspectives. International Journal of Qualitative Methods, 5(3), 1-11.

Ethical Consumer Report (2017) Markets Report 2017, Triodos Bank/Ethical Consumer, Manchester.

Farrokhi, F. \& Mahmoudi-Hamidabad, A. (2012). Rethinking convenience sampling: Defining quality criteria. Theory and Practice in Language Studies, 2(4), 784-792.

Freestone, O.M. \& McGoldrick, P.J. (2008). Motivations of the ethical consumer. Journal of Business Ethics, 79(4), 445-467.

Gianluigi, G. (2009). Behind ethical consumption: Purchasing motives and marketing strategies for organic food products, non-GMOs, bio-fuels. Peter Lang, New York.

Gregory-Smith, D., Smith, A. and Winklhofer, H. (2013). Emotions and dissonance in 'ethical' consumption choices. Journal of Marketing Management, 29(11-12), 1201-1223.

Guest, G., Bunce, A. \& Johnson, L. (2006). How many interviews are enough?: An experiment with data saturation and variability. Field Methods,18(1), 59-82.

Harrison, R., Newholm, T. \& Shaw, D. (2005). The Ethical Consumer, Sage Publications, London.

Hassan, L. M., Shiu, E., \& Shaw, D. (2016). Who says there is an intention-behaviour gap? Assessing the empirical evidence of an intention-behaviour gap in ethical consumption. Journal of Business Ethics, 136(2), 219-236.

House, R.J. \& Wigdor, L.A. (1967). Herzberg's dual-factor theory of job satisfaction and motivation: A review of the evidence and a criticism. Personnel Psychology, 20(4), 369-390.

Jägel, T., Keeling., K., Reppel, A. \& Gruber, T. (2012). Individual values and motivational complexities in ethical clothing consumption: A means-end approach. Journal of Marketing Management, 28(3-4), 373-396.

Janis, I.L. \& Mann, L. (1977). Decision Making: A Psychological Analysis of Conflict, Choice and Commitment. Free Press, New York.

Keynote. (2015). Green and Ethical Consumer Markets Report, March 2015. $7^{\text {th }}$ ed. Keynote Limited, England. 
Klooster, J. V. \& Meryer, M. (2015). Ethical banking - a primer [online]. Available from: http://www.jbs.cam.ac.uk/fileadmin/user_upload/research/centres/compliancetrust/downloads/trustinbankingmaterials-ethicalbanking.pdf [accessed 16 August, 2016].

Langeland, L. (1998). On communicating the complexity of a green message. Greener Management International, 25, 81-91.

Lewis, A. (2001). A focus group study of the motivation to invest: 'ethical/green' and 'ordinary' investors compared. The Journal of Socio-Economics, 30(4), 331-341.

Lewis, A. \& Mackenzie, C. (2000). Support for investor activism among U.K. ethical investors. Journal of Business Ethics, 24(3), 215-222.

Lincoln, Y.S. \& Guba, E.G. (1985). Naturalistic Inquiry. Sage Publications, Newbury Park. Maslow, A.H. (1943). A theory of human motivation. Psychological Review, 50(4), 370-396. Maslow, A.H. (1970a). Motivation and Personality. Harper \& Row. New York.

Maslow, A. H. (1970b). Religions, Values, and Peak Experiences. Penguin, New York.

Mason, M. (2010). Sample size and saturation in $\mathrm{PhD}$ studies using qualitative interviews. Forum qualitative Sozialforschung/Forum 11(3). Available from: http://www.qualitativeresearch.net/index.php/fqs/article/view/1428/3027 [accessed 16 August, 2016].

McEachern, M.G. (2015) Corporate citizenship and its impact upon consumer moralization, decision-making and choice, Journal of Marketing Management, 31(3-4), 430-452.

McEachern, M.G. \& Warnaby, G. (2008). Exploring the relationship between consumer knowledge and purchase behaviour of value-based labels. International Journal of Consumer Studies, 32(5), 414-426.

McEachern, M. \& Carrigan, M. (2012). Re-visiting contemporary issues in green/ethical marketing: An introduction to the special issue. Journal of Marketing Management, 28(3-4), 189-194.

Memery, J., Megicks, P. \& Williams, J. (2005). Ethical and social responsibility issues in grocery shopping: A preliminary typology. Qualitative Market Research, 8, 399-412.

Meo, A.I. (2010). Picturing students' habitus: The advantages and limitations of photoelicitation interviewing in a qualitative study in the city of Buenos Aires. International Journal of Qualitative Methods, 9(2), 149-171.

Miles, M.B. \& Huberman, A.M. (1994). Qualitative Data Analysis :An Expanded Sourcebook. Sage Publications, Thousand Oaks.

Mitchell, W.J., Lewis, P.V. \& Reinsch, N.L. (1992). Bank ethics: An exploratory study of ethical behaviors and perceptions in small, local banks. Journal of Business Ethics, 11(3), 197-205. 
Moisander, J. (2007). Motivational complexity of green consumerism. International Journal of Consumer Studies, 31(4), 404-409.

Moorthy, S., Ratchford, B.T. \& Talukdar, T. (1997). Consumer information search revisited: Theory and empirical analysis. Journal of Consumer Research, 23, 263-277.

Move Your Money. (2014). The Move Your Money Bank Ranking Scorecard [online]. Available from: http://moveyourmoney.org.uk/scorecard-explained/ [accessed 24 August, 2016].

Move Your Money (2016). Campaigns. [online] Available at:

http://moveyourmoney.org.uk/campaigns/ [accessed 12 June, 2016].

Move Your Money. (2017). Move Your Money [online] Available from:

https://medium.com/move-your-money/the-move-your-money-bank-ranking-scorecard$\underline{327 \mathrm{c} 4 \mathrm{~d} 6 \mathrm{e} 2073}$ [accessed 27 August, 2017].

Myers, M. (1997). Qualitative research in information systems. Management Information Systems Quarterly, 21(2), 241-242.

Oh, J.C. \& Yoon, S.J. (2014). Theory-based approach to factors affecting ethical consumption. International Journal of Consumer Studies, 38(3), 278-288.

Oswick, C. \& Montgomery, J. (1999). Images of an organisation: The use of metaphor in a multinational company. Journal of Organizational Change Management, 12(6), 501-523.

Ozcaglar-Toulouse, N., Shiu, E. \& Shaw, D. (2006). In search of fair trade: Ethical consumer decision making in France. International Journal of Consumer Studies, 30(5), 502-514.

Patton, M.Q. (2002). Qualitative Research and Evaluation Methods. Sage Publications, Thousand Oaks.

Prochaska, J.O., DiClemente, C.C. and Norcross, J.C. (1992). In search of how people change. Applications to addictive behaviors. The American Psychologist, 47(9), 1102-1114.

Ritchie, J. \& Lewis, J. (2003). Qualitative Research Practice : A Guide for Social Science Students and Researchers. Sage Publications, California.

Schröder, M.J.A. \& McEachern, M.G. (2004) Consumer value conflicts surrounding ethical food purchase decisions: A focus on animal welfare, International Journal of Consumer Studies, 28(2), 168-177.

Shaw, D. \& Clarke, I. (1999). Belief formation in ethical consumer groups: An exploratory study. Market Intelligence and Planning, 17(2-3), 109-119.

Shenton, A.K. (2004). Strategies for ensuring trustworthiness in qualitative research projects. Education for Information, 22, 63-75. 
Solomon, M.R., Bamossy, G., Askegaard, S. \& Hogg, M. K. (2016). Consumer Behaviour : A European Perspective. $5^{\text {th }}$ ed. Prentice Hall: Financial Times, London.

Steinman, R. (2009). Projective techniques in consumer research. International Bulletin of Business Administration, 5(1), 37-45.

Straus, R.R. (2015). A new mis-selling scandal could see bank customers pocket a $£ 33 B I L L I O N$ windfall - so what did banks do wrong and will you receive compensation? [online]. Available from: http://www.thisismoney.co.uk/money/saving/article3192262/Latest-PPI-bank-misselling-scandal-windfall.html [accessed 16 August, 2016]

Sudbury-Riley, L., Kohlbacher, F. \& Hofmeister, A. (2012). A cross-cultural analysis of proenvironmental consumer behaviour among seniors. Journal of Marketing Management, 28(34), 290-312.

Supphellen, M. (2000). Understanding core brand equity: Guidelines for in-depth elicitation of brand associations. International Journal of Market Research, 40(3), 319-338.

Szmigin, I., Carrigan, M. \& McEachern, M.G. (2009). The conscious consumer: taking a flexible approach to ethical behaviour. International Journal of Consumer Studies, 33(2), 224-231.

The Financial Brand (2010). 7 tips to find your brand's personality. [online]. Available from: http://thefinancialbrand.com/14053/bank-credit-union-branding-personality-attributes/ [accessed 16 August, 2016].

Thomas, D.R. (2006). A general inductive approach for analyzing qualitative evaluation data. American Journal of Evaluation, 27(2), 237-246.

Treanor, J. \& Rushe, D. (2012). HSBC pays record \$1.9bn fine to settle US moneylaundering accusations. The Guardian, [online]. Available from:

https://www.theguardian.com/business/2012/dec/11/hsbc-bank-us-money-laundering [accessed 16 August, 2016].

Uusitalo, O. \& Oksanen, R. (2004). Ethical consumerism: a view from Finland. International Journal of Consumer Studies, 28(3), 214-221.

Velicer, W.F., DiClemente, C. C., Prochaska, J. O. \& Brandenburg, N. (1985). Decisional balance measure for assessing and predicting smoking status. Journal of Personality and Social Psychology, 48(5), 1279- 1289.

Vermeir, I. \& Verbeke, W. (2008). Sustainable food consumption among young adults in Belgium: Theory of planned behaviour and the role of confidence and values. Ecological Economics, 64(3), 542-553. 
Welsh, E. (2002). Dealing with Data: Using NVivo in the Qualitative Data Analysis Process. Forum Qualitative Sozialforschung / Forum: Qualitative Social Research 3(2). [online]. Available from: http://www.qualitative-research.net/index.php/fqs/article/view/865/1880 [Accessed 1st May, 2016].

Xiao, J.J. \& O'Neill, B. (2016). Consumer financial education and financial capability. International Journal of Consumer Studies, 40(6), 712-721.

Yamoah, F. A., Duffy, R., Petrovici, D. \& Fearne, A. (2014). Towards a framework for understanding Fairtrade purchase intention in the mainstream environment of supermarkets. Journal of Business Ethics, 1-17.

Young, W., Hwang, K., McDonald, S. \& Oates, C.J. (2010). Sustainable consumption: green consumer behaviour when purchasing products. Sustainable Development, 18(1), 20-31. 
Table 1 Ethical Scorecard for UK Financial Service Providers ${ }^{4}$

\begin{tabular}{|c|c|c|c|c|c|c|c|c|c|c|c|c|c|c|c|c|c|}
\hline \multirow[b]{2}{*}{ Provider } & \multicolumn{4}{|c|}{ Honesty } & \multicolumn{4}{|c|}{ Customer Service } & \multicolumn{4}{|c|}{ Culture } & \multicolumn{3}{|c|}{$\begin{array}{c}\text { Supporting the } \\
\text { Economy }\end{array}$} & \multicolumn{2}{|c|}{ Scores } \\
\hline & $\stackrel{\mathscr{0}}{\stackrel{0}{\Xi}}$ & 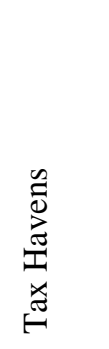 & 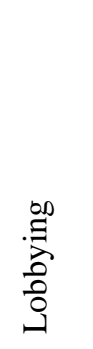 & 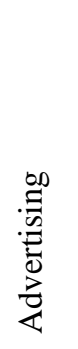 & 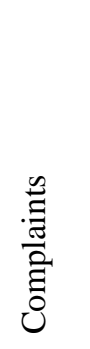 & 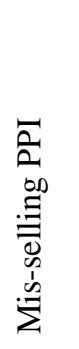 & 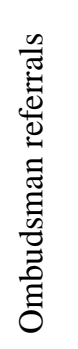 & 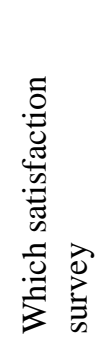 & 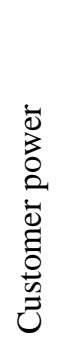 & 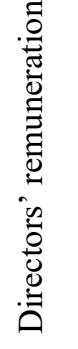 & 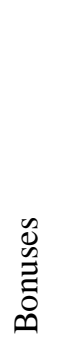 & 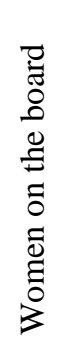 & $\begin{array}{l}\bar{\sigma} \\
0 \\
0 \\
.00 \\
.00 \\
0 \\
0 \\
0\end{array}$ & 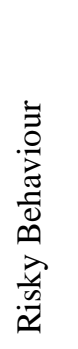 & 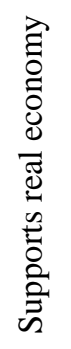 & 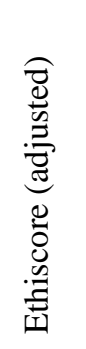 & 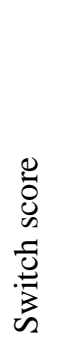 \\
\hline Ecology BS & & & $\checkmark$ & $\checkmark$ & $\checkmark$ & & $\checkmark$ & $\checkmark$ & $\checkmark$ & $\checkmark$ & & & & & & 12 & 100 \\
\hline Triodos Bank & & & 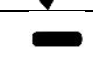 & $\sqrt{ }$ & $\checkmark$ & $V$ & $\gamma$ & & C & $\gamma$ & $\checkmark$ & & & $V$ & & 12 & 92 \\
\hline Nationwide BS & $\infty$ & $\checkmark$ & - & $\checkmark$ & $x$ & $x$ & $x$ & $\checkmark$ & $\checkmark$ & $x$ & $x$ & & $\checkmark$ & $\checkmark$ & $\checkmark$ & 11 & 64 \\
\hline Chelsea BS & $x$ & $\checkmark$ & - & $\checkmark$ & $x$ & $x$ & $x$ & $\checkmark$ & $\checkmark$ & - & $x$ & & & $\checkmark$ & $\checkmark$ & 11 & 63 \\
\hline Co-operative Bank & $\infty$ & - & $x$ & $\checkmark$ & - & $x$ & $x$ & $\checkmark$ & - & $x$ & $\checkmark$ & & $\checkmark$ & $\checkmark$ & $x$ & 8 & 51 \\
\hline Post Office Ltd & $x$ & $x$ & - & $\checkmark$ & $x$ & - & - & $x$ & $x$ & - & $\checkmark$ & & $x$ & $\checkmark$ & - & 8 & 41 \\
\hline Santander Bank & $x$ & $x$ & $x$ & - & $x$ & $\infty$ & - & $x$ & $x$ & $x$ & $x$ & & $x$ & - & - & 5 & 25 \\
\hline Halifax Bank & $x$ & $x$ & - & $x$ & $x$ & $x$ & $x$ & $x$ & $x$ & $x$ & $x$ & & $x$ & $\sigma$ & - & 4 & 21 \\
\hline NatWest & $x$ & $x$ & $x$ & $x$ & $x$ & $x$ & $x$ & $x$ & $x$ & $x$ & $x$ & $\checkmark$ & $x$ & $x$ & $x$ & 1 & 7 \\
\hline $\begin{array}{l}\text { Royal Bank of } \\
\text { Scotland }\end{array}$ & $x$ & $x$ & $x$ & $x$ & $x$ & $x$ & $x$ & $x$ & $x$ & $x$ & $x$ & $\checkmark$ & $x$ & $x$ & $x$ & 1 & 7 \\
\hline Barclays & $x$ & $x$ & $x$ & $x$ & $x$ & $x$ & $x$ & $x$ & $x$ & $x$ & $x$ & - & $x$ & $x$ & $x$ & 1 & 4 \\
\hline
\end{tabular}

Source: Move Your Money (2014)

${ }^{4}$ More information on the methodology used for the Ethical Scorecard can be read on their Website (Move Your Money, 2017) 
Table 2 Participant Information

\begin{tabular}{|c|c|c|c|c|}
\hline Pseudonym & Occupation & Age & Children & $\begin{array}{c}\text { Financial Service } \\
\text { Provider }\end{array}$ \\
\hline Alexander & Student & 23 & No & $\begin{array}{l}\text { Co-operative Bank } \\
\text { Halifax Bank }\end{array}$ \\
\hline Rebecca & Retired, Farmer & 83 & Yes & $\begin{array}{l}\text { Nationwide Building Soc. } \\
\text { Danske Bank }\end{array}$ \\
\hline Kate & Radiographer & 54 & Yes & $\begin{array}{l}\text { Nationwide Building Soc. } \\
\text { Danske Bank }\end{array}$ \\
\hline Belle & Dentist & 55 & Yes & $\begin{array}{l}\text { Chelsea Building Soc. } \\
\text { Natwest } \\
\text { Barclays }\end{array}$ \\
\hline Matthew & Retired, Bank Official & 55 & Yes & $\begin{array}{l}\text { Nationwide Building Soc. } \\
\text { Credit Union } \\
\text { First Trust Bank } \\
\text { Post Office Ltd }\end{array}$ \\
\hline Sarah & $\begin{array}{l}\text { Supportive Housing } \\
\text { Officer }\end{array}$ & 23 & No & $\begin{array}{l}\text { Nationwide Building Soc. } \\
\text { Natwest }\end{array}$ \\
\hline Richard & Production Analyst & 23 & No & $\begin{array}{l}\text { Co-operative Bank } \\
\text { Santander Bank }\end{array}$ \\
\hline
\end{tabular}


Figure 1 Stages of Ethical Awareness, Concern and Action

\begin{tabular}{|c|c|c|c|c|c|}
\hline $\begin{array}{c}\text { 1. Not } \\
\text { noticed this } \\
\text { issue }\end{array}$ & $\begin{array}{c}\text { 2. Aware but } \\
\text { not greatly } \\
\text { concerned }\end{array}$ & $\begin{array}{c}\text { 3. Aware and } \\
\text { concerned but } \\
\text { have not taken } \\
\text { action }\end{array}$ & $\begin{array}{c}\text { 4. Concerned } \\
\text { and intend to } \\
\text { take action }\end{array}$ & $\begin{array}{c}\text { 5. Concerned } \\
\text { and taken } \\
\text { minor action }\end{array}$ & $\begin{array}{c}\text { 6. Concerned } \\
\text { and taken } \\
\text { major action }\end{array}$ \\
\hline
\end{tabular}

Source: Adapted from Freestone and McGoldrick (2008), p.452 
Figure 2 Revised Stages of Ethical Awareness, Concern and Action

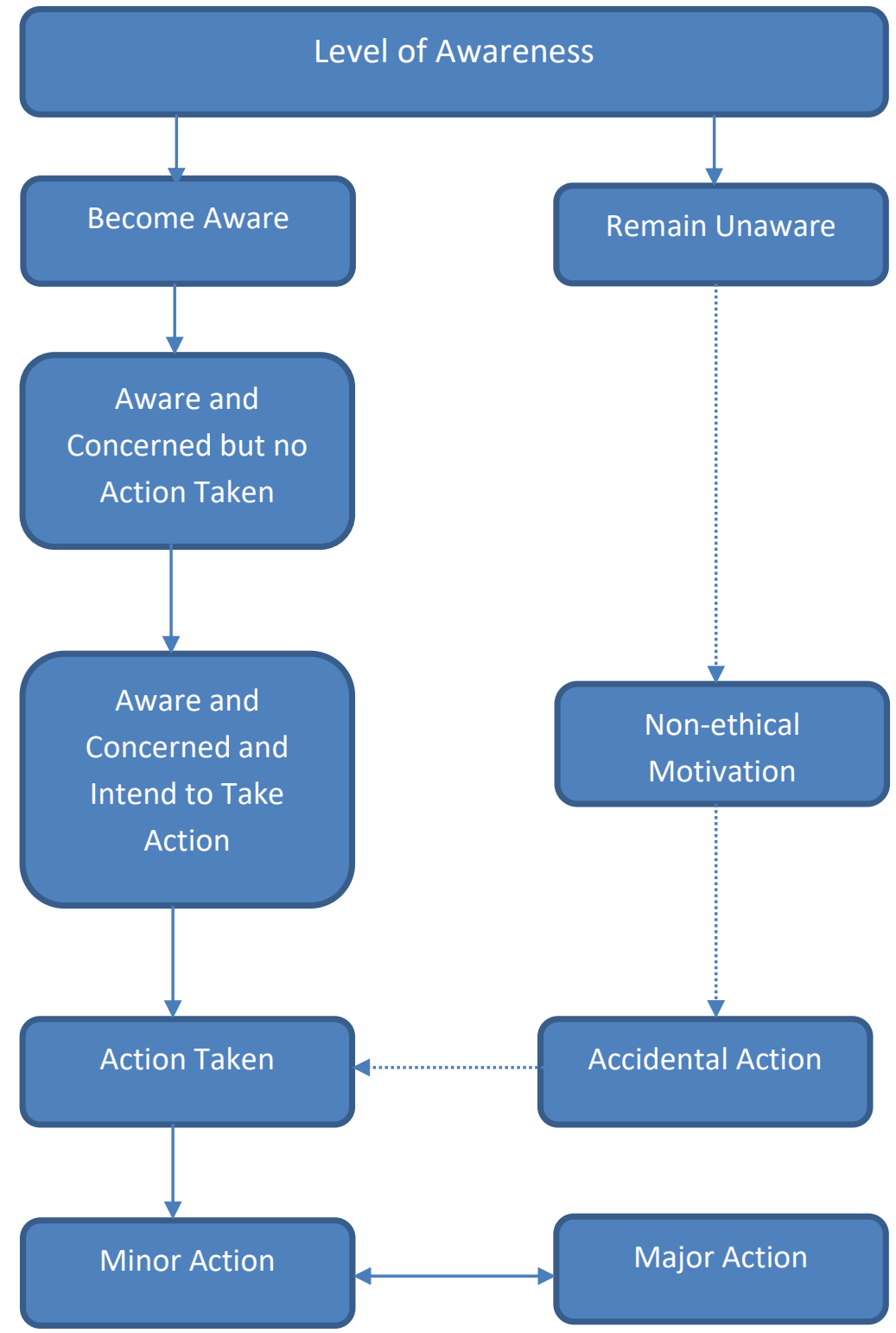

